\title{
MATRIX OF DEPENDENCE OF MUNICIPALITIES IN THE NORTH REGION OF GOIÁS
}

\author{
https://doi.org/10.4215/rm2020.e19028
}

\author{
Antonio Pasqualetto ${ }^{a^{*}}$ - Ubirajara de Lima Ferreira b - Fudio Matsuura ${ }^{c}$
}

(a) PhD in Phytotechnics. Prof. Pontifical Catholic University of Goiás, Goiânia (GO), Brazil.

ORCID: http://orcid.org/0000-0002-8639-6725. LATTES: http://lattes.cnpq.br/4691515540448143.

(b) Master in Territorial Development and Planning. Pontifical Catholic University of Goiás, Goiânia (GO), Brazil.

ORCID: https://orcid.org/0000-0001-5822-8620. LATTES: http://lattes.cnpq.br/3333449370815726.

(c) Master in Territorial Development and Planning. Professor at the Federal Institute of Education, Science and Technology of Goiás, Goiânia (GO), Brazil.

ORCID: https://orcid.org/0000-0002-0467-6871. LATTES: http://lattes.cnpq.br/5868284529680160.

\author{
Article history: \\ Received 29 June, 2020 \\ Accepted 07 August, 2020 \\ Publisher 15 December, 2020
}

(*) CORRESPONDING AUTHOR

Address: PUC-GO - Avenida Universitária, Setor Leste Universitário. CEP: 74605010, Goiânia (GO), Brasil. Phone: (+55 62) 39461351

E-mail: profpasqualetto@gmail.com

\section{Abstract}

Of the total number of municipalities in the northern region of the State of Goiás, part of them have their own revenues below requirements, if current conditions are maintained, they tend to be incorporated into neighboring municipalities from 2025 onwards in compliance with PEC $188 / 2019$. Would there be an alternative for municipal development and sustainability without the necessary population increase? In this sense, the purpose was to identify the economic and social weaknesses that characterize the municipalities in the northern region and to create a "Dependency Matrix". The methodology consisted of consulting databases of federal, state and municipal agencies and programs. The results demonstrate the low level of economic activity, own revenues, high dependence on external revenues, high payroll on civil clerk, exposing themselves to the dictates of the Fiscal Responsibility Law (LRF) and high dependence on the Income Transfer Programs of the Federal Government such as the Bolsa Família Program (PBF) and the Continuous Payment Benefit (BPC). The Dependency Matrix assists the municipal manager in restraining the alleged migratory flight, the loss of economic relevance, as well as economic, environmental and social sustainability.

Keywords: Dependency Matrix. Economy. Sustainability.

\section{Resumo / Resumen}

\section{MATRIZ DE DEPENDÊNCIA DOS MUNICÍPIOS DA REGIÃO NORTE DE GOIÁS}

Do total de municípios da região norte do Estado de Goiás, parte possuem receitas próprias inferiores às necessidades, a se manterem as condições atuais, tendem a ser incorporados a municípios vizinhos a partir de 2025 em obediência à PEC 188/2019. Haveria alternativa para o desenvolvimento e a sustentabilidade municipal sem o necessário incremento populacional? Neste sentido, objetivou-se identificar as fragilidades econômicas e sociais que caracterizam os municípios da região norte e criar "Matriz de Dependência". A metodologia consistiu na consulta de bases de dados de órgãos e programas federais, estaduais e municipais. Os resultados demonstram o baixo nível de atividade econômica, de receitas próprias, elevada dependência de receitas externas, elevada folha de pagamento dos servidores, expondo-se aos ditames da Lei de Responsabilidade Fiscal (LRF) e alta dependência dos Programas de Transferência de Renda do Governo Federal como o Programa Bolsa Família (PBF) e o Benefício de Prestação Continuada (BPC). A Matriz de Dependência auxilia o gestor municipal na contenção da suposta fuga migratória, da perda de relevância econômica e da sustentabilidade econômica, ambiental e social.

Palavras-chave: Matriz de Dependência. Economia. Sustentabilidade.

\section{MATRIZ DE DEPENDENCIA DE MUNICIPIOS EN LA REGIÓN NORTE DE GOIÁS}

Del total de municipios de la región norte del Estado de Goiás, parte de ellos tiene ingresos propios por debajo de los requisitos, si se mantienen las condiciones actuales tienden a incorporarse a los municipios vecinos a partir de 2025 en cumplimiento de la PEC 188/2019. ¿Habría una alternativa para el desarrollo y la sostenibilidad municipal sin el aumento de población necesario? En este sentido, el objetivo era identificar las debilidades económicas y sociales que caracterizan a los municipios de la región norte y crear una "Matriz de dependencia". La metodología consistió en consultar bases de datos de agencias y programas federales, estatales y municipales. Los resultados demuestran el bajo nivel de actividad económica, los ingresos propios, la alta dependencia de los ingresos externos, la alta nómina de los funcionarios públicos, la exposición a los dictados de la Ley de Responsabilidad Fiscal (LRF) y la alta dependencia de los Programas de Transferencia de Ingresos del Gobierno federal como el Programa Bolsa Familia (PBF) y el Beneficio de pago continuo (BPC). La matriz de dependencia ayuda al gerente municipal a contener el supuesto vuelo migratorio, la pérdida de relevancia económica y la sostenibilidad económica, ambiental y social.

Palabras-clave: Matriz de dependencia. Economía. Sustentabilidad. 


\section{INTRODUCTION}

The Municipal Participation Fund (MPF) is the primary source of revenue for Brazilian municipalities. It is provided for in Title VI - Taxation and Budget, Chapter I - National Tax System and Section VI - Tax Revenue Sharing, of Article 159 of the Federal Constitution - FC (BRASIL, 1988). The article addresses the transfer of responsibility from the Union to municipalities, which is proportional to the number of residents.

The Union reserves $22.5 \%$ for the MPF, and so, the municipalities, from $49 \%$ of the Income Tax (IT) and the Tax on Industrialized Products (TIP) collected, plus 1\% from July through to December, based on the rules of the Decree-Law $n^{\circ} 1881 / 1981$.

There are 26 municipalities in the Northern Region of the State of Goiás, $16(62 \%)$ of which receive transfers in the range of $0.6 \%$ of the Municipal Participation Fund (MPF). This sum is $86 \%$ of the $22.5 \%$ of monies destined to municipalities in the interior of the State, which depend directly on them to fund their activities, especially the Public Servants Payroll, as according to the 2010 IBGE Census, they have a population of fewer than 10,188 inhabitants (TCU, 2020 and IBGE, 2019).

This article analyzes a worrying factor for municipal managers and the population of small Brazilian municipalities, especially in the Northern Region of Goiás, given that the Executive Branch has sent PEC 188/2019 (BRAZIL, 2019) to the National Congress. This bill proposes the merger of small municipalities with up to 5,000 inhabitants and whose internal revenues are limited to $10 \%$ of the total revenue, which indicates the systematic and gradual loss of their economic relevance and the contraction in the number of residents. Simultaneously, in most municipalities in the Northern Region of Goiás, there has been a worsening dependence on the FPM, the BFP, and the CPB over the last 30 years (1989/2019).

In response to this scenario, bibliographic research and examinations of renowned institutes' databases were carried out to analyze the aspects that explain the troubling and systematic economic decay of small Brazilian municipalities, evidenced by their strong dependence on external resources. Special attention was paid to the Northern Region of the State of Goiás, focusing on economic, social, and environmental sustainability.

To this end, the objective was to create a "Municipal Dependency Matrix," based on the data and information obtained, including the resident population, internal and external revenues, the employed population, and beneficiaries of the Federal Government's social programs. The aim was to understand the factors that have brought about the gradual and consistent decay, loss of economic relevance, and population decline between 1989-2019.

\section{LITERATURE REVIEW}

According to Hirschimann (1961), many traditional development theories converge towards the thesis that it occurs unevenly and timelessly in the face of territory and time.

Gomes and Mac Dowell (2000) report that political decentralization, the proliferation of municipal units, and the increase in tax resources appropriated by these entities have not brought about positive results.

When analyzing the profile of municipalities in the State of Paraná, in terms of their uneven geographic development, Costa and Rocha (2014) observed that the inequalities established between the regions led to winners and losers. In the former, the economy grows and society tends to become more prosperous. In the latter, the accumulation process stagnates, and society tends to fall below the existing poverty levels.

The most dynamic municipalities exert a regional influence, reproducing the capitalist model of development better. The factors that attract new inhabitants include more significant job generation derived due to the presence of small, medium, and large industries, diversified commerce and services, active radio and television broadcasters, locally published newspapers, broadband internet coverage, and infrastructure with highways that facilitate the flow of people and goods and connectivity with other municipalities (COSTA and ROCHA, 2014). 
According to Costa and Rocha (2014), peripheral municipalities, further away from the capital and the more developed regions, have little regional influence and struggle to meet the population's basic needs (health, education, employment, income, housing, among others). The poverty rate is high, and many of the residents move away from the municipalities.

Article Six of the Federal Constitution (CF 1988). updated by the Constitutional Amendment $\mathrm{n}^{\circ}$. 90 of September 15, 2015, sets out the Social Rights guaranteed to citizens:

Art. 6. Education, health, nutrition, labor, housing, leisure, security, social security, protection of motherhood and childhood, and assistance to the destitute are social rights under this Constitution. (BRAZIL), 1988).

Next, Article Seven of the FC deals with the provision of social security, professional qualification, and entry to the job market; Articles 205 and 208 affirm the universal right to high-quality education, which is the duty of the State and the Family. Furthermore, Article 144 addresses the guarantee, protection, and stability of public security, as well as social coexistence, protection, and the defense of rights.

Henceforth, the State became primarily responsible for improving the population's quality of life, through the Constitution, by developing health support programs such as the Unified Health System (SUS), income transfer programs such as the Bolsa Família (BFP) that unified and brought together under the same roof former programs such as the Bolsa Escola, Bolsa Alimentação, Auxílio Gás (schooling, food, and cooking fuel).

Despite the genuine objective of income transfer programs, such as the BFP, there are questions about whether they could harm the local economy by inhibiting the search for work and employment and postpone the prospect of reversing dependency. However, Correa Junior et al. (2019) claim that the BFP may have the opposite effect on the labor market in Brazilian municipalities, as in addition to not causing adverse impacts, it can also cause salary increases in the municipality. They state:

From the perspective of public policy management, the finding that the BFP is positively associated with the formal labor market in Brazilian municipalities is understood as a real and effective contribution, both concerning the increase in employed persons and through the increase in wages and other income. (CORREA JUNIOR et al., 2019, p. 856).

This statement highlights the BFP's importance in meeting the most vulnerable social groups' immediate primary needs and contributing directly to the increase in employment and local income.

When analyzing the fiscal policy between 1999/2014, Gobetti and Orair (2015) considered the trend for gradual growth in social spending, regardless of periods of economic contraction and expansion:

The main factor behind the expansion of this expenditure is the vegetative growth in the number of beneficiaries, whether due to constitutionally guaranteed rights, which have been progressively enacted, demographic pressures, or the effect of the labor market's formalization. Irrespective of the causes, the fact is that the number of beneficiaries grew at an average rate of almost $4 \%$ per year in just over a decade (GOBETTI and ORAIR, 2015, p. 438).

Parallel to the growth in the number of beneficiaries, the authors also identified a rise in central government spending on social benefits as a proportion of the Gross Domestic Product (GDP), in the period 1998/2014, of the order of 5.86\% (1998), 6.74\% (2002), 8.28\% (2006), 8.24\% (2010), 8.61\% (2012), and 9.29\% (2014).

It is difficult to imagine the continued expansion of benefits as a proportion of the country's GDP over the next decade, given the frequent global economic crises and the discussions about the high tax burden that, together with low productivity and high production costs, are considered factors that inhibit economic growth.

Such an analysis requires the study of indicators over a certain period, encompassing the economic and social order realities in the study area. This is the aim of the present work, using 
municipal, state, and federal institutions to focus on the North Region of the State of Goiás.

Given the country's continental dimensions and its inequalities, the construction of a Dependency Matrix reflects a dialogue with the Brazilian geographic system, distributed in regions with similar characteristics.

The term "Matrix" was borrowed from the world of mathematics and refers to the set of rows and columns used to organize data, to facilitate the understanding and resolution of problems, numerical or not.

The term "Dependency," in turn, refers to the reality marked by the low revenue from local taxation, the weight of the public sector payroll, and the scarcity of resources for investments, which naturally generates a permanent need to find external resources to maintain the municipal administration.

Regarding the Northeast region, Ugeda (2020) shows the chronology of the decrees and laws passed to mitigate the issue of regional inequality, culminating in the creation of the Ministry of Regional Development - MRD in 2019 and the institution of the National Policy for Regional Development - NPRD through Decree ${ }^{\circ}$. 9810/2019 of 05/30/2019, due to the relevance of the theme.

Based on this situation, which is the reality for most small Brazilian municipalities, regardless of geography, the present study focused on those located in the north of the State of Goiás, to draw up a demonstration spreadsheet called the "Municipal Dependency Matrix" that simultaneously shows the low tax collection capacity and the high dependence on external resources to fund the municipal administrative structure.

\section{METHODOLOGY}

\section{CHARACTERIZATION OF THE NORTHERN REGION OF THE STATE OF GOIAS}

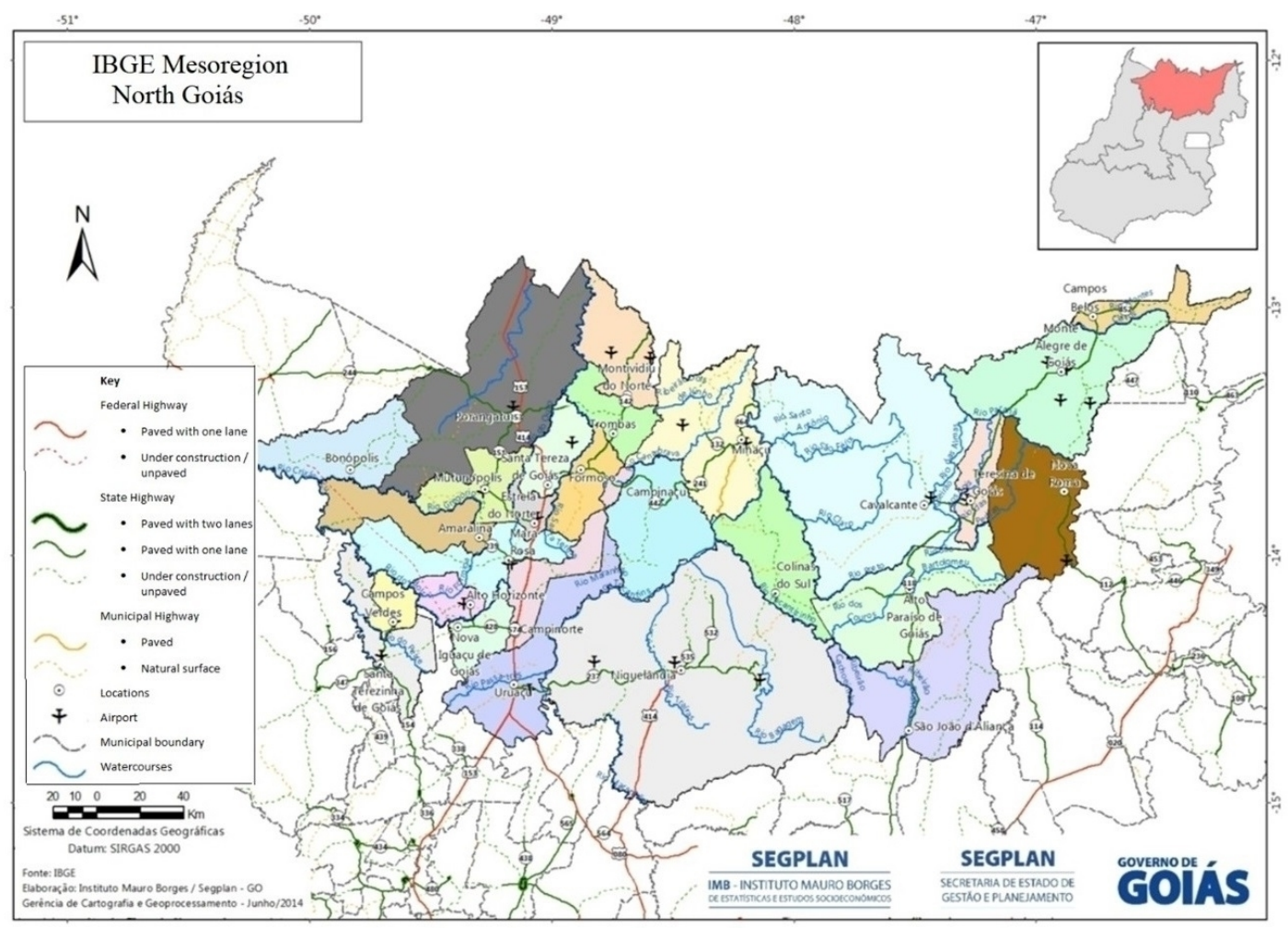

Figure 1- IBGE Mesoregion - North Goiás. Source: Prepared by IMB / SEGPLAN / IBGE - Instituto Mauro Borges (2014) and the authors' adaptations. 
The Northern Region of the State of Goiás is composed of 26 municipalities. It is neighbored by the south of the State of Tocantins, by the northeast region of the State of Goiás to the east, and by the State of Mato Grosso to the west.

The location map shows its geographical position in the north of the State of Goiás (Figure 1).

The municipalities in the mesoregion are Alto Horizonte, Amaralina, Bonópolis, Campinaçu, Campinorte, Campos Verdes, Crixás, Estrela do Norte, Formoso, Mara Rosa, Minaçu, Montividiu do Norte, Mozarlândia, Mundo Novo, Mutunópolis, Niquelândia, Nova Crixás, Nova Iguaçu de Goiás, Novo Planalto, Porangatu, Santa Tereza de Goiás, Santa Terezinha de Goiás, São Miguel do Araguaia, Trombas, Uirapuru and Uruaçu.

\section{DATA COLLECTION}

The research was carried out in 2019 to consult data on portals and agencies such as the Ministry of Regional Development (MRD), Ministry of Social Development (MSD), Ministry of Finance and National Treasury Secretariat, Transparency Portal (CGU), Economic Research Institute of Applied Science (IPEA), Brazilian Institute of Geography and Statistics (IBGE), State Secretariat for Social Development (2019), Mauro Borges Institute (IMB), the Citizen's Portal, and the Tribunal of Municipal Accounts (TCM). The objective was to understand the low levels of activity and the dependence on the transfer of government resources that marks small Brazilian municipalities' reality.

The variables considered were classified as follows:

a) Characterization of the Municipalities: Area $\left(\mathrm{km}^{2}\right)$, date of creation of the municipality of origin, population density $/ \mathrm{km}^{2}$

b) Level of economic activity: Participation in the collection of State Value-Added Tax (ICMS) in the Regions of the State of Goiás

c) Dependence on external sources of funds: municipalities' participation fund

d) Public Servant's Payroll: Federal, State, and municipal

e) Creation of the "Dependency Matrix" for the municipalities in the northern region of the State of Goiás, based on population, internal revenues, government transfers, payroll, and beneficiaries of federal programs.

To allow for better analysis and interpretation, the data is presented in figures and tables.

\section{MUNICIPALITIES IN THE NORTH REGION OF THE STATE OF GOIÁS AND THE DEPENDENCY MATRIX}

\section{MUNICIPALITIES IN THE NORTHERN REGION OF GOIÁS}

The emancipation of the first municipalities in the Northern Region of the State of Goiás began in the 1930s; however, most were created in the 1950s and 1960s. There was a spatial fragmentation process giving rise to new municipalities in the region, especially in the late 1980s and early 1990s ( Table 1). 


\begin{tabular}{|c|c|c|c|c|c|}
\hline Decades & Municipalities & Area $\left(\mathbf{k m}^{2}\right)$ & Date created & $\begin{array}{l}\text { Municipality } \\
\text { of origin }\end{array}$ & $\begin{array}{c}\text { Demographic } \\
\text { density } \\
\text { inhab./km² } \\
(2017)\end{array}$ \\
\hline $\begin{array}{l}\text { 19th CENTURY - } \\
1833\end{array}$ & Niquelândia & $9,843.25$ & 04/01/1833 & Pirenópolis & 4.66 \\
\hline 1930/1939 & Uruaçu & $2,141.82$ & 07/04/1931 & Pilar de Goiás & 18.71 \\
\hline 1940/1949 & Porangatu & $4,820.52$ & $8 / 25 / 1948$ & Uruaçu & 9.40 \\
\hline \multirow{5}{*}{ 1950/1959 } & Mara Rosa & $1,687.84$ & 08/26/1953 & Uruaçu & 6.06 \\
\hline & Crixás & $4,661.17$ & $10 / 30 / 1953$ & Itapaci & 3.62 \\
\hline & Estrela do Norte & 301.64 & $11 / 14 / 1958$ & Porangatu & 11.20 \\
\hline & Mutunópolis & 955.88 & $11 / 14 / 1958$ & Porangatu & 4.09 \\
\hline & $\begin{array}{l}\text { São Miguel Do } \\
\text { Araguaia }\end{array}$ & $6,148.80$ & $11 / 14 / 1958$ & Porangatu & 3.69 \\
\hline \multirow{5}{*}{ 1960/1969 } & Campinorte & $1,067.19$ & $10 / 8 / 1963$ & Uruaçu & 11.55 \\
\hline & Formoso & 844.29 & $9 / 25 / 1963$ & Mara Rosa & 5.48 \\
\hline & Mozarlandia & $1,734.36$ & $10 / 23 / 1963$ & Goiás & 8.72 \\
\hline & $\begin{array}{l}\text { Santa Terezinha } \\
\text { de Goiás }\end{array}$ & $1,202.25$ & $10 / 23 / 1963$ & Pilar de Goiás & 8.00 \\
\hline & $\begin{array}{l}\text { Santa Tereza de } \\
\text { Goiás }\end{array}$ & 794.56 & $11 / 13 / 1963$ & Porangatu & 4.67 \\
\hline 1970/1979 & Minaçu & $2,860.74$ & 05/14/1976 & Uruaçu & 10.73 \\
\hline \multirow{6}{*}{ 1980-1989 } & Mundo Novo & $2,146.65$ & $6 / 10 / 1980$ & Crixás & 2.64 \\
\hline & Nova Crixás & $7,302.23$ & $6 / 10 / 1980$ & Crixás & 1.75 \\
\hline & Campinaçu & $1,974.38$ & 05/14/1982 & Uruaçu & 1.89 \\
\hline & Campos Verdes & 441.65 & 01/27/1988 & $\begin{array}{l}\text { Santa } \\
\text { Terezinha de } \\
\text { Goiás } \\
\end{array}$ & 7.70 \\
\hline & Novo Planalto & $1,242.96$ & 01/27/1988 & $\begin{array}{l}\text { Sao Miguel do } \\
\text { Araguaia }\end{array}$ & 3.53 \\
\hline & Trombas & 799.13 & $01 / 27 / 1988$ & Formoso & 4.47 \\
\hline \multirow{6}{*}{$1990-1999$} & Alto Horizonte & 503.76 & $1 / 16 / 1991$ & Mara Rosa & 11.48 \\
\hline & $\begin{array}{l}\text { Nova Iguaçu de } \\
\text { Goiás }\end{array}$ & 628.44 & 1/16/1991 & Mara Rosa & 4.71 \\
\hline & $\begin{array}{l}\text { Montividiu do } \\
\text { Norte }\end{array}$ & $1,333.00$ & $4 / 29 / 1992$ & Trombas & 3.34 \\
\hline & Uirapuru & $1,153.48$ & 4/29/1992 & Crixás & 2.57 \\
\hline & Amaralina & $1,343.24$ & $12 / 27 / 1995$ & Mara Rosa & 2.79 \\
\hline & Bonópolis & $1,628.49$ & $12 / 27 / 1995$ & Porangatu & 2.54 \\
\hline
\end{tabular}

Table 1 - Municipalities in the Northern Region of Goiás - Emphasis on creation/emancipation by decade. Source: IBGE (2019), Instituto Mauro Borges - Segplan-GO (2018), adapted by the authors.

Of these municipalities, nine (34\%) have been emancipated since 1988, shortly after the promulgation of the Federal Constitution (BRASIL, 1988), notably the emergence of Campos Verde, the site of emerald mines, which separated from Santa Terezinha de Goiás in 1988.

\section{LEVEL OF ECONOMIC ACTIVITY, DECENTRALIZATION, AND MUNICIPAL REVENUE COLLECTION CAPACITY}

Following the analysis of the level of economic activity, Table 2 shows the municipalities' contribution to the ICMS collection by region in the State of Goiás. In 2000, the northern region raised $2.06 \%$ of the state total, falling to $1.99 \%$ in 2010 and $1.04 \%$ in 2017 , according to an IMB (2018) survey. 


\begin{tabular}{l|r|r|r}
\hline \multicolumn{1}{c|}{ Region } & \multicolumn{1}{c|}{$\mathbf{2 0 0 0}$} & \multicolumn{1}{c|}{$\mathbf{2 0 1 0}$} & \multicolumn{1}{c}{$\mathbf{2 0 1 7}$} \\
\hline 001 - Goiás Metropolitan & 58.47 & 56.63 & 58.03 \\
\hline 002 - Goiás Center & 7.07 & 7.33 & 8.05 \\
\hline $\mathbf{0 0 3}$ - Goiás North & $\mathbf{2 . 0 6}$ & $\mathbf{1 . 9 9}$ & $\mathbf{1 . 0 4}$ \\
\hline 004 - Goiás Northeast & 0.27 & 0.42 & 0.23 \\
\hline 005 - Surroundings of the Federal & 2.27 & 3.30 & 3.35 \\
District & 2.63 & 4.22 & 2.82 \\
\hline 006 - Goiás Southeast & 3.88 & 3.50 & 2.53 \\
\hline 007 - Goiás South & 5.81 & 4.86 & 4.35 \\
\hline 008 - Goiás Southwest & 1.68 & 1.15 & 0.95 \\
\hline 009 - Goiás West & 0.37 & 0.31 & 0.29 \\
\hline 010 - Goiás Northwest & 15.48 & 16.29 & 18,35 \\
\hline Others & $\mathbf{1 0 0 . 0 0}$ & $\mathbf{1 0 0 . 0 0}$ & $\mathbf{1 0 0 . 0 0}$ \\
\hline STATE OF GOIÁS & & &
\end{tabular}

Table 2 - Participation in the collection of ICMS in the Planning Regions - Northern Region of the State of Goiás. Source: Mauro Borges Institute / SEGPLAN-GO (2018) adapted by the authors.

The drop in the percentage contribution of the North Region to the State's ICMS from 2000 to 2017 (from $2.06 \%$ to $1.04 \%$ ) is evidence of its lower economic dynamism when compared to the other regions, which has a direct effect on employment and income, aspects that may cause the population reduction that has occurred over time.

Most regions showed stagnation, apart from the Central Region, the Federal District's surroundings, and the Metropolitan Region of the capital (Goiânia, Aparecida, Anápolis, Senador Canedo, Trindade), which benefitted from their power of attraction.

The impact of a lower level of economic activity in the municipalities is noteworthy as it results in lower jobs and income generation, less internal revenue from taxes, levies, and contributions such as the IPTU/ISS/ITBI, greater dependence on external transfers such as the MPF and Parliamentary Amendments to fund activities and investments, and more reliance on social programs such as the $\mathrm{BFP} / \mathrm{CPB}$ by the unemployed and the low-income population.

The fiscal decentralization that started in the 1980s was unplanned and resulted from the conflicts between the Union, the States, and the Municipalities due to the concentration of federal tax collection and the increasing transfers of responsibilities to the states and municipalities, starting from the 1988 Federal Constitution.

As observed by the authors Guedes and Gasparini (2007), the municipalities were mainly strengthened by constitutional transfers that affected their capacity to raise revenue.

The high degree of the municipalities' financial dependence is explained by their tax revenues' modest performance, resulting from the current tax structure, which reserves the highest value taxes to the Union and the States. Also, taxation is still highly concentrated in the state capitals and the country's largest cities, especially in the more developed regions (GUEDES AND GASPARINI, 2007, p. 304)

In a way, municipalities have become used to the regular transfer of resources. Many even fail to collect the Municipal Property Tax (IPTU) and maintain low rates of Municipal Service Tax (ISSQN) to avoid unpopularity by updating their tax codes and collecting taxes.

\section{DEPENDENCE ON EXTERNAL SOURCES}

The Municipal Participation Fund (MPF) is a constitutional transfer (CF, Art. 159, I, b) from the Union to the States and the Federal District to Brazilian municipalities, comprising $22.5 \%$ of the $49 \%$ reserve from the collection of Income Tax (IT) and Tax on Industrialized Products (IPI) (BRASIL, 1988). It takes place monthly using a coefficient based on the number of residents, according to studies 
by IBGE (2019).

The distribution of resources to the municipalities based on the number of inhabitants uses fixed population ranges, each having an individual coefficient. The criteria used to calculate the municipalities' participation coefficients are based on Law No. 5,172 / 66 (National Tax Code) and Decree-Law No. 1,881 / 81 (BRASIL, 1966; BRASIL, 1981).

Based on this legislation, the IBGE publishes population statistics for the municipalities. The Federal Court of Accounts (FCA) uses this data to calculate and publish the municipalities' coefficients in the Official Gazette by the last business day of the year. The transfer percentages for the state capitals and the Federal District are 10.0\%, and "Reserve" municipalities with a population above 156,216 inhabitants receive 3.6\%, based on DL 1881/1981, changed by Complementary Law - LC 91/1997 to 142,633 inhabitants. All other municipalities (the interior) receive 86.4\%, as shown in Figure 2.

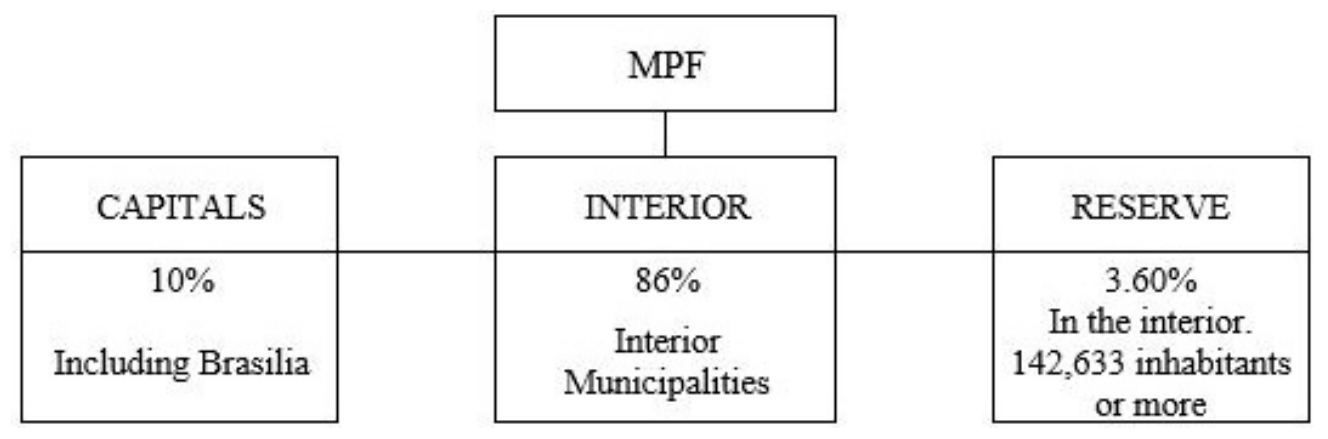

Figure 2 - Percentage distribution of MPF resources. Source: Ministry of Finance, National Treasury Secretariat (2018), adapted by the authors.

A lower internal revenue index causes a greater dependence on external resources, such as the MPF, Parliamentary Amendments, and others for municipal management. There is also a greater need for income transfer programs such as the BFP and CBP to avoid social chaos.

\section{PUBLIC SERVANT PAYROLL}

The impact of public sector payroll on municipal accounts is well known, leading the federal government to pass the Law of Fiscal Responsibility (LFR), which as part of its function to improve public administration, aims to inhibit the rise of expenses linked to functionalism. If not observed, offending municipal administrators may even lose their mandate and face imprisonment.

The LFR - Complementary Law 101/2000, a code of conduct for public administrators throughout Brazil, aims to preserve the fiscal situation of the Union, States, Municipalities, and the Federal District. The provisions of the Agência Senado include limits on expenses with personnel.

The Union can only spend up to $50 \%$ of its current net revenue. States, Municipalities, and the Federal District are limited to $60 \%$. If the expense reaches $95 \%$ of the established limit, the granting of benefits, the creation of positions and jobs, and overtime payment, among other items, are prohibited. LCP 101/2000, Casa Civil. (BRASIL, 2000)

The Atlas of the Brazilian State 1986/2017 published by IPEA in 2019, identified that the Brazilian public sector increased $132 \%$ in 32 years; however, the report states that

Only one in ten civil servants is at the federal level. The increase in public servants observed in the data series is concentrated in the municipalities. In the period analyzed, the number of municipal employment links increased by $276 \%$, compared to $50 \%$ at the state level and $28 \%$ at the federal level (both civil and military). 
In the municipalities, $40 \%$ of occupations are education or health professionals, namely, teachers, doctors, nurses, and health agents ( LOPEZ and GUEDES, 2019).

Since the promulgation of the 1988 Constitution (CF 1988), functions previously performed by the Federal and State Governments have gradually been transferred to the municipalities, mainly in the health service. When analyzed in isolation, this aspect would explain the rise in the number of employees in the municipalities.

Figure 3 shows the stratification of three decades of the Brazilian public sector (1986/2017) based on IPEA calculations (2017), emphasizing the concentration of growth in the number of public servants at the municipal level.

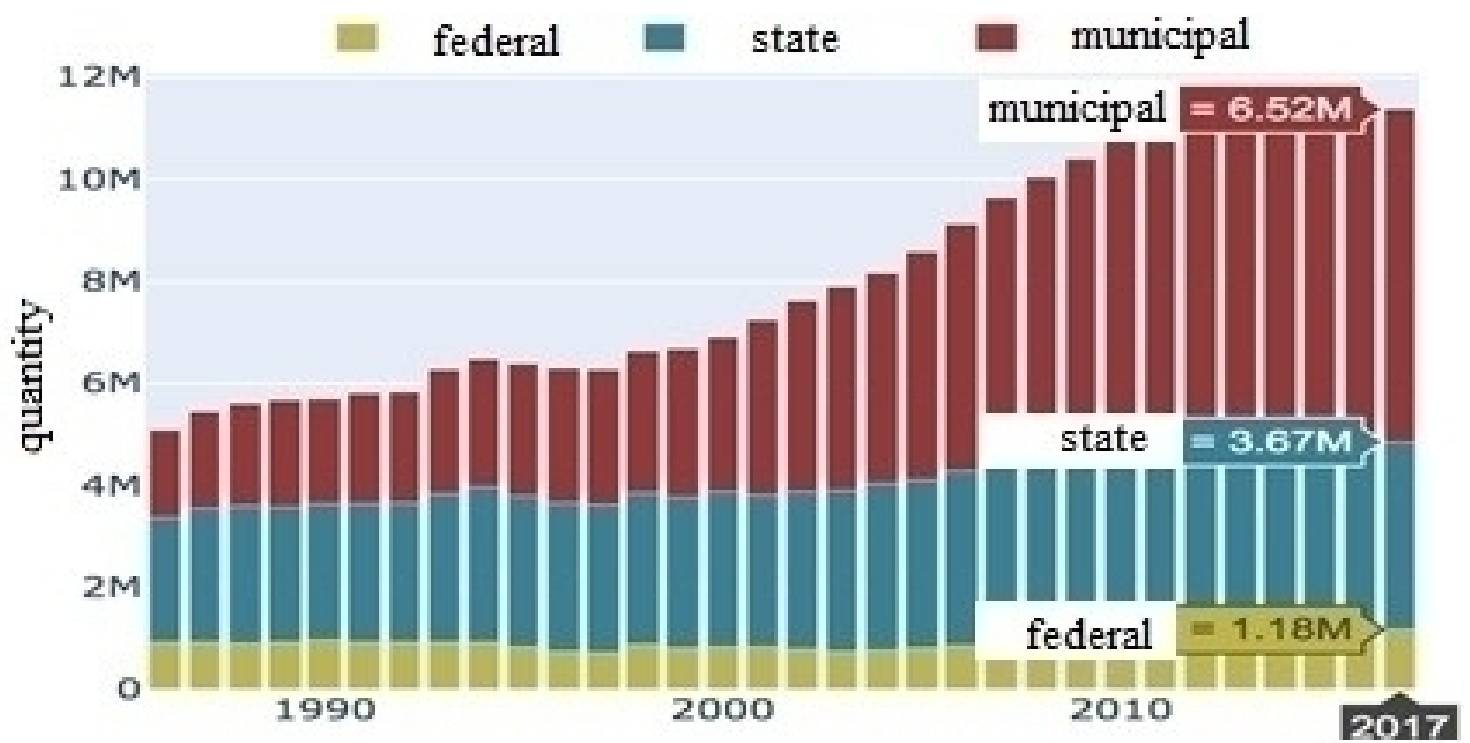

Figure 3 - Total public bonds, by federative level, emphasizing the growth of municipal employees (1986/2017). Source: Atlas of the Brazilian State - IPEA cited by Lopez and Guedes (2019).

Figure 4 shows the evolution of public servants in the State of Goiás, within the scope of the executive, legislative, and judicial powers at the federal, state, and municipal levels.

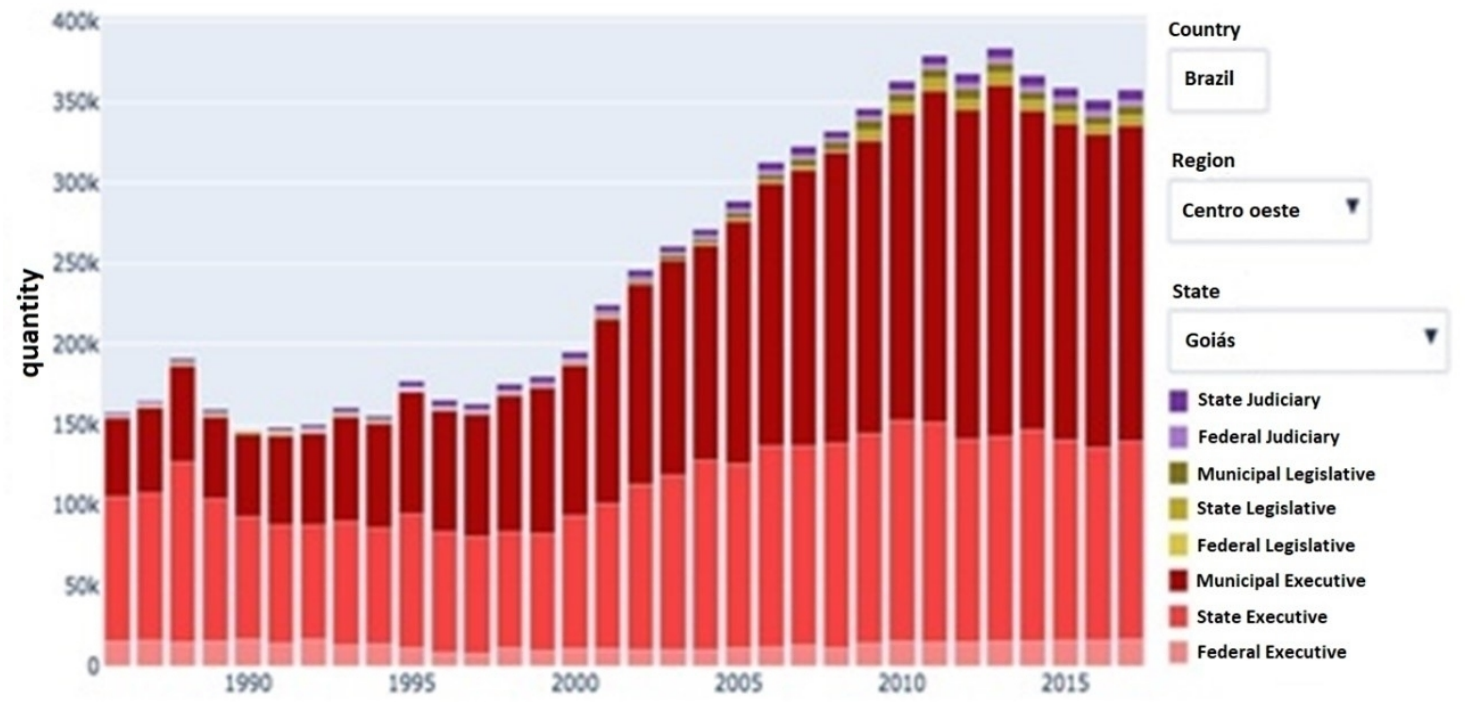

Figure 4 - Stratification of public servants in the State of Goiás at the federal, state, and municipal levels (1986/2017). Source: Atlas of the Brazilian State / IPEA cited by Lopez and Guedes (2019). 


\section{MUNICIPAL DEPENDENCY MATRIX}

According to Hirschimann (1961), there are no Development Poles among the municipalities of the Northern Region of the State of Goiás that exercise a wider influence and extrapolate their territorial limits. The only influencers are Sub Poles with lower attractiveness, such as Uruaçu, Porangatu, Niquelândia, and Minaçu.

The peripheral municipalities, further away from the capital and the more developed regions, have little influence over their local area and struggle to meet the population's basic needs, such as health, education, employment, income, and housing. The poverty rates are high, and many residents move away. Costa and Rocha (2014) state that these aspects are common to the municipalities in the Northern Region of the State of Goiás and accentuate the negative factors.

The Municipal Dependency Matrix presented below is based on the data set; it allows municipal managers to understand the sources and uses of resources, payroll commitments and identify beneficiaries of the Bolsa Família and Continuing Benefit programs in the municipality. These elements evidence the receipt of external resources that prevent investments and improvements that promote citizens' quality of life.

Given the lack of investment, the future is not promising, undermining education, health, and safety, which causes residents, especially young people, to migrate in search of job opportunities.

Over the years, the lack of enticements for the "repatriation" of the successful younger migrants means that the older residents, some retired from the INSS and beneficiaries of the government assistance programs, remain in the municipalities, as shown in Table 3.

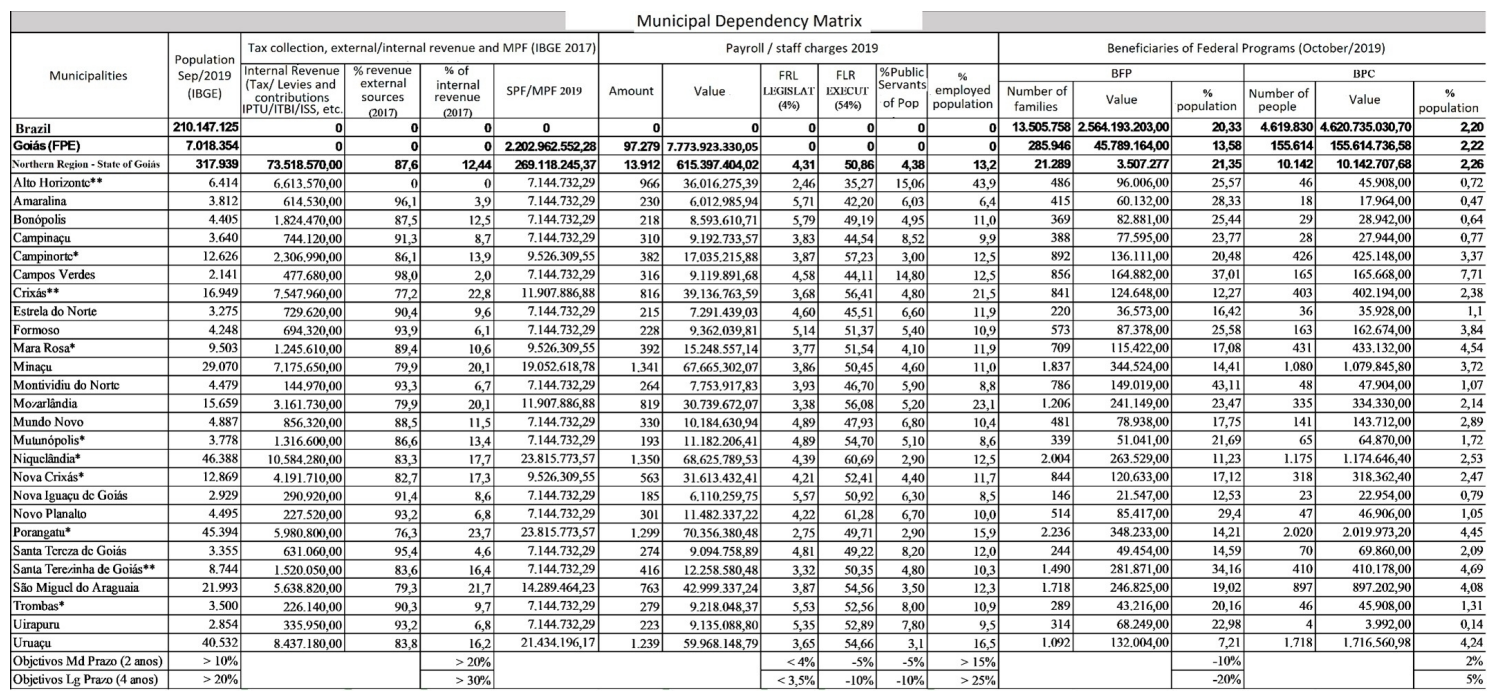

Table 3 - Dependency Matrix of the municipalities in the Northern Region of the State of Goiás.Sources: IBGE (2019), MDS (2019), Citizen Portal TCM (2020), Transparency Portal CGE (2019), and the State Secretariat for Social Development (2019) National Treasury (2020), adapted by the authors.

** External revenue data, 2014. * External revenue data, 2015.

To act as a reliable compass for municipal management, the Dependency Matrix presents a range of data, including the small contingent of residents, the low municipal revenue, the high volume of revenue from external sources such as the FPM, the proportion of the public payroll of civil compared to revenues and population, the low percentage of the population in employment, and the percentage of families and people dependent on BFP and CPB in most municipalities, which is higher than the average for the State of Goiás and Brazil.

These aspects have weakened municipalities to the point of making them economically unfeasible, which puts them at the mercy of the Constitutional Amendment Proposal $n^{\circ} 188 / 2019$, the PEC of the Federative Pact. The proposal was sent by the federal executive branch to the National 
Congress in November / 2019 and recommended the unification of municipalities with up to 5,000 inhabitants and whose own revenues are limited to $10 \%$ of their total revenue, as noted in art. 115

Art. 115. Municipalities of up to five thousand inhabitants must prove their financial sustainability by June $30,2023$.

$\S 1^{\circ}$ A municipality's financial sustainability shall be attested with proof that the respective proceeds from collecting the taxes referred to in art. 156 of the Federal Constitution corresponds to at least ten percent of its revenue.

$\S 2 \circ$ The municipality that does not prove its financial sustainability shall be incorporated into one of its neighboring municipalities, as of January 1, 2025.

$\S 3$ The municipality with the best financial sustainability index will be the incorporator. (BRAZIL, 2019)

Although the subject will be widely discussed in the National Congress, based on these premises and current conditions, approximately 50\% (13/26) of the municipalities in the Northern Region of the State of Goiás may merge with neighboring municipalities from January 2025, as proposed by PEC 188/2019 (SENADO, 2019).

Careful analysis of the Dependency Matrix shown in Table 3 demonstrates that:

a) 11 of the 26 municipalities in the northern region $(42 \%)$ do not even collect $10 \%$ of their total revenue, and 14 of them (54\%) have less than 5,000 inhabitants. This situation compromises their viability and subjects them to the dictates of PEC 188/2019;

b) the low level of local economic activity plus the lack of initiative to decentralize municipal tax collection will result in low internal revenues (IPTU / ISS / ITBI / Others). The result will be insolvency issues that may delay the payment of suppliers and public servants' salaries and pensions;

c) the high number of municipal employees and payroll costs ( $>40 \%$ of revenues) will lead to a high dependence on external resources (FPM / Parliamentary Amendments, political, and others) and will imply non-compliance with the Law of Fiscal Responsibility - LFR $(>60 \%$ of expenses with executive and legislative functions);

d) the high dependence on the Federal Government's Income Transfer Programs (Bolsa Família Program, Continuous Payment Benefit, and Others) will maintain the low population occupancy and continue the poverty cycle, generating widespread dissatisfaction, migration, and social chaos.

An increase in economic activity levels reduces these municipalities' dependence on external resources, which naturally generates employment and income.

The service sector can positively influence the generation of municipal revenue. According to Salgado et al. (2014), the Tax on Municipal Services - ISSQN has the highest municipal revenue in Alto Paraíso.

Furthermore, a study of the megatrends that will impact the Brazilian economy by 2035, carried out by the Institute for Applied Economic Research - IPEA predicts an increase in the dependency ratio of the weight of the inactive population (from 0 to 14 years and 65 years and older) compared to the potentially active population (15 to 64 years old). This dependence will undoubtedly put even more pressure on the social protection system (Bolsa Família Programs, Continuing Benefit Programs, among others) and compromise their demographic and financial sustainability (IPEA, 2017).

Therefore, it is crucial to realize that if a municipality's dependency ratio is 11 older adults per 100 inhabitants in 2015, this number is estimated to rise to 23 in 2035 and 36 in 2050. Thus, it is strategic for administrators to diagnose the reasons behind their municipality's dependence and embark on public policies to attract new residents as soon as possible.

According to Correia Junior et al. (2019), the BFP can have a positive effect on the labor market in municipalities; nevertheless, it can lead to conformity and inhibit the public sector and the local population from intensifying their search for increased economic activity and the generation of jobs and income, which are essential for local development. 
Gobetti and Orair (2015) highlight the gradual growth in the number of social programs' beneficiaries and their proportion of the GDP. Their skepticism about these income transfer programs complements our understanding of how difficult it will be to maintain the current levels and evolution in the coming decades, considering economic crises, the already high tax burden, and the contemporary debate regarding the minimal State.

\section{CONCLUSION}

The Municipal Dependency Matrix simultaneously reflects the predominant weakness in most municipalities in the northern region of the State of Goiás, given their low economic activity and the reduced volume of internal revenues.

Public managers will be able to use the medium and long-term recommendations in the Dependency Matrix to guide their strategic planning and implement measures aiming to contain the loss of economic relevance and avoid the steady migration of residents.

Expanding economic activity levels to generate employment, income, and tax revenues, leading to improvements in education, health, and safety, thus achieving a better quality of life and increasing the territory's economically active population is a challenge and a mandatory public management exercise in current times.

Hence the importance of involving public managers and the population in studies that identify municipal limitations and potential in the quest to modernize the municipal tax framework.

The Dependency Matrix should be applied on a case-by-case basis, for each municipality, given each particular context to better represent the local reality. According to the executive and legislative branches' strategy, short, medium, and long-term goals and targets are required to achieve municipal development.

\section{ACKNOWLEDGEMENTS}

We are grateful for the support of the Coordination for the Improvement of Higher Education Personnel - Brazil (CAPES) and the Research Support Foundation of the State of Goiás (FAPEG).

\section{REFERENCES}

BRASIL. Constituição da República Federativa do Brasil de 1988. Brasília, DF: Presidência da República. Disponível em: http://www.planalto.gov.br/ccivil_03/constituicao/constituicao.htm. Acesso: 26 out. 2019 e 29 jun. 2020.

BRASIL. I PEC Do Pacto Federativo. Senado recebe pacote do governo para mudar pacto federativo e regras fiscais. Senado, 2019. Disponível em: https://www12.senado.leg.br/noticias/materias/2019/11/05/senado-recebe-novo-pacote-de-reformas-dogoverno. Acesso: 07 nov. 2019.

BRASIL. Lei de Responsabilidade Fiscal - LRF 101/2000. Lei Complementar n. 101, de 4 de maio de 2000. Extraído em: http://www.planalto.gov.br/ccivil_03/leis/lcp/lcp101.htm. Acesso em: 01 mar. 2020.

CORREA JÚNIOR, Carlos Barbosa; TREVISAN, Leonardo Nelmi; MELLO, Cristina Helena Pinto. Impacto do Programa Bolsa Família no Mercado de Trabalho dos Municípios Brasileiros. Revista Administração Pública, Rio de Janeiro, v. 53, n.5, p. 838-858. Set./dez. 2019.

COSTA, Fábio Rodrigues e ROCHA, Márcio Mendes. Nova Dinâmica dos Municípios do Paraná. 2014. Disponível em: https://doi.org/10.4215/RM2014.1302.0007 Acesso em: 28 jun. 2020.

GOBETTI, Sérgio Wulff; ORAIR, Rodrigo Octávio. Política fiscal em perspectiva: o ciclo de 16 anos (1999-2014). Economia Contemporânea. Rio de Janeiro, v. 19, n. 3, p. 417-447, dezembro de 2015. 
GOMES, G.M.; MAC DOWEL M. C. Descentralização política, federalismo fiscal e criação de municípios: o que é mau para o econômico nem sempre é bom para o social. Brasília: Ipea, fev. 2000. (Texto para Discussão, 706).

GUEDES, Kelly Pereira e GASPARINI, Carlos Eduardo. Descentralização fiscal e tamanho do governo no Brasil. Economia Aplicada, Ribeirão Preto, v. 11, n. 2, p. 303-323, Apr. /jun., 2007.

HIRSCHMAN, Albert Otto. Estratégia do desenvolvimento econômico. Rio de

Janeiro: Fundo de Cultura S.A., 1961.p. 68.

INSTITUTO BRASILEIRO DE GEOGRAFIA E ESTATÍSTICA - IBGE. Estimativas da População. $2019 . \quad$ Disponível em: https://www.ibge.gov.br/estatisticas/sociais/populacao/9103-estimativas-de-populacao.html? $=\& \mathrm{t}=\mathrm{resulta}$ dos. Acesso em: 12 nov. 2019.

INSTITUTO BRASILEIRO DE GEOGRAFIA E ESTATÍSTICA - IBGE. Conheça cidades e estados do Brasil. Extraído em: https://cidades.ibge.gov.br/ Acesso em: 25 fev. 2020.

INSTITUTO DE PESQUISA ECONÔMICA APLICADA - IPEA. Brasil 2035. Cenários para o Desenvolvimento. Dimensão Econômica. Aumento da razão de dependência na população brasileira. Governo Federal: 2017, p. 133.

INSTITUTO MAURO BORGES. Estatísticas municipais. Disponível: https://www.imb.go.gov.br/index.php?option=com_content\&view=article\&id=91\&Itemid=219 Acesso 10 fev. 2020.

INSTITUTO MAURO BORGES. Gerência de cartografia e geoprocessamento. Mesorregião do IBGE Norte Goiano. Goiânia, 2014.

INSTITUTO MAURO BORGES. Gerência de Sistematização e Disseminação de Informações Socioeconômicas. Participação na arrecadação do ICMS nas Regiões de Planejamento. Goiânia, 2018.

LOPEZ, Felix; GUEDES, Erivelton. Atlas do Estado Brasileiro. Três décadas de evolução do funcionalismo público no Brasil (1986-2017). 2019. Extraído em https://www.ipea.gov.br/atlasestado/filtros-series. Acesso em: 19 mai. 2020.

MINISTÉRIO DO DESENVOLVIMENTO SOCIAL. MDS. Bolsa Família e Cadastro Único no seu município. Disponível em: https://aplicacoes.mds.gov.br/sagirmps/bolsafamilia/relatorio-completo.html. Acesso: 22 nov. 2019.

MINISTÉRIO DA FAZENDA, Secretaria do Tesouro Nacional. Distribuição percentual dos recursos do FPM. Brasília. 2018

PORTAL DO CIDADÃO. Tribunal de Contas. Acompanhe aqui a movimentação dos recursos do Estado de Goiás. Extraído em: https://www.tcm.go.gov.br/pentaho/api/repos/cidadao/app/index.html. Acesso: 19 mai. 2020.

PORTAL DA TRANSPARÊNCIA. Controladoria Geral da União. Recursos do Governo Federal aplicados na localidade. Disponível em: http://www.portaltransparencia.gov.br/localidades/GO-goias?ano=2019. Acesso em: 19 mai. 2020.

SALGADO, Thatiana Rodrigues; VIANA, Juheina Lacerda Ribeiro; ARAGÃO, Ana Luiza Santana. Impactos da atividade turística à economia municipal de Alto Paraíso de Goiás, Brasil. Mercator, Fortaleza, v. 13, n. 3 p. 75-91. 2014.

SECRETARIA DE ESTADO DE DESENVOLVIMENTO SOCIAL - SEDS. Coordenação do Programa Bolsa Família. Percentual de Famílias Beneficiárias do PBF e do BPC nos municípios da Região Norte de Goiás. Resposta a consulta do autor em novembro/2019. Retificada em fevereiro/2020.

SENADO NOTÍCIAS. Agência Senado. Infomatérias. LRF - Lei de Responsabilidade Fiscal. Extraído em: https://www12.senado.leg.br/noticias/entenda-o-assunto/lrf. Acesso em: 01 mar. 2020. 
TESOURO NACIONAL. Transferências Constitucionais. Extraído em: http://sisweb.tesouro.gov.br/apex/f?p=2600:1::IR_962295:NO::.. Acesso em: 01 mar. 2020 e 21 mai. 2020.

TRIBUNAL DE CONTAS DA UNIÃO - TCU. Transferências constitucionais e legais. Coeficientes FPE $\quad$ e FPM. Extraído em: https://portal.tcu.gov.br/transferencias-constitucionais-e-legais/coeficientes-fpe-e-fpm/. Acesso em: 01 mar. 2020.

UGEDA, Luiz. Desenvolvimento regional e desafios da construção jurídica do Nordeste. Mercator, Fortaleza, v.19, e19016, p. 7-15, 2020. 